\title{
Uusioersily
}

\section{Metal Removal from Contaminated Soils Through Bioleaching with Oxidizing Bacteria and Rhamnolipid Biosurfactants}

Diaz, M. A., de Ranson, I. U., Dorta, B. D., Banat, I., Blazquez, M. L., Gonzalez, F., Muñoz, J. A., \& Ballester, A. (2015). Metal Removal from Contaminated Soils Through Bioleaching with Oxidizing Bacteria and Rhamnolipid Biosurfactants. Soil and Sediment Contamination: An International Journal, 24(1), 16-29.

https://doi.org/10.1080/15320383.2014.907239

Link to publication record in Ulster University Research Portal

Published in:

Soil and Sediment Contamination: An International Journal

Publication Status:

Published (in print/issue): 01/01/2015

DOI:

10.1080/15320383.2014.907239

\section{Document Version}

Author Accepted version

\section{General rights}

Copyright for the publications made accessible via Ulster University's Research Portal is retained by the author(s) and / or other copyright owners and it is a condition of accessing these publications that users recognise and abide by the legal requirements associated with these rights.

\section{Take down policy}

The Research Portal is Ulster University's institutional repository that provides access to Ulster's research outputs. Every effort has been made to ensure that content in the Research Portal does not infringe any person's rights, or applicable UK laws. If you discover content in the Research Portal that you believe breaches copyright or violates any law, please contact pure-support@ulster.ac.uk. 
This article was downloaded by: [The University of Manchester Library], [Mayri Diaz]

On: 09 October 2014, At: 02: 26

Publisher: Taylor \& Francis

Informa Ltd Registered in England and Wales Registered Number: 1072954 Registered office: Mortimer House, 37-41 Mortimer Street, London W1T 3J H, UK

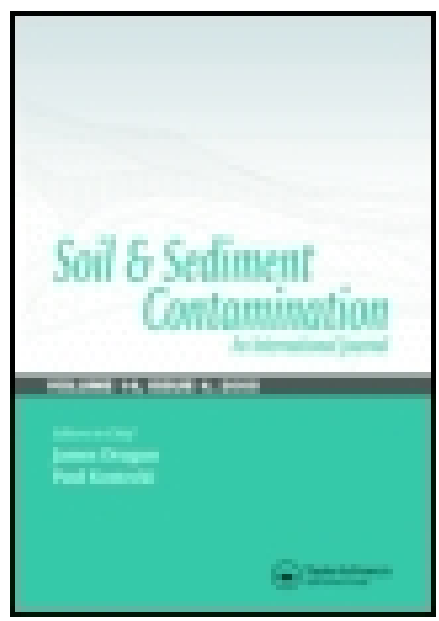

\title{
Soil and Sediment Contamination: An International J ournal
}

Publication details, including instructions for authors and subscription information: http:// www.tandfonline.com/loi/ bssc20

\section{Metal Removal from Contaminated Soils Trough Bioleaching with Oxidizing Bacteria and Rhamnolipid Biosurfactants}

\author{
Mayri A. Diaz ${ }^{a}$, Isora Urdaneta de Ranson ${ }^{b}$, Blas Dorta Dorta ${ }^{b}$, Ibrahim M. Banat ${ }^{a}$, Maria L. \\ Blazquez ${ }^{c}$, Felisa Gonzalez ${ }^{c}$, J esús A. Muñoz ${ }^{c} \&$ Antonio Ballester ${ }^{c}$ \\ ${ }^{a}$ School of Biomedical Sciences, Faculty of Life \& Health Sciences, University of Ulster, BT52 \\ 1SA, Northern Ireland, UK \\ ${ }^{\mathrm{b}}$ Laboratorio de Procesos Fermentativos, Instituto de Biología Experimental, Facultad de \\ Ciencias, Universidad Central De Venezuela, 1010A, Caracas-Venezuela \\ ' Departamento de Ciencia de Materiales e Ingeniería Metalúrgica, Facultad de Ciencias \\ Químicas, Universidad Complutense de Madrid, 28040 Madrid-Spain \\ Accepted author version posted online: 20 May 2014.
}

To cite this article: Mayri A. Diaz, Isora Urdaneta de Ranson, Blas Dorta Dorta, Ibrahim M. Banat, Maria L. Blazquez, Felisa Gonzalez, J esús A. Muñoz \& Antonio Ballester (2014): Metal Removal from Contaminated Soils Trough Bioleaching with Oxidizing Bacteria and Rhamnolipid Biosurfactants, Soil and Sediment Contamination: An International J ournal, DOI: 10.1080/15320383.2014.907239

To link to this article: http:// dx. doi.org/ 10.1080/15320383.2014.907239

Disclaimer: This is a version of an unedited manuscript that has been accepted for publication. As a service to authors and researchers we are providing this version of the accepted manuscript (AM). Copyediting, typesetting, and review of the resulting proof will be undertaken on this manuscript before final publication of the Version of Record (VoR). During production and pre-press, errors may be discovered which could affect the content, and all legal disclaimers that apply to the journal relate to this version also.

\section{PLEASE SCROLL DOWN FOR ARTICLE}

Taylor \& Francis makes every effort to ensure the accuracy of all the information (the "Content") contained in the publications on our platform. However, Taylor \& Francis, our agents, and our licensors make no representations or warranties whatsoever as to the accuracy, completeness, or suitability for any purpose of the Content. Any opinions and views expressed in this publication are the opinions and views of the authors, and are not the views of or endorsed by Taylor \& Francis. The accuracy of the Content should not be relied upon and should be independently verified with primary sources of information. Taylor and Francis shall not be liable for any losses, actions, claims, proceedings, demands, costs, expenses, damages, and other liabilities whatsoever or howsoever caused arising directly or indirectly in connection with, in relation to or arising out of the use of the Content.

This article may be used for research, teaching, and private study purposes. Any substantial or systematic reproduction, redistribution, reselling, loan, sub-licensing, systematic supply, or distribution in any 
form to anyone is expressly forbidden. Terms \& Conditions of access and use can be found at http:// www.tandfonline.com/page/terms-and-conditions 


\section{ACCEPTED MANUSCRIPT}

\section{METAL REMOVAL FROM CONTAMINATED SOILS TROUGH BIOLEACHING WITH OXIDIZING BACTERIA AND RHAMNOLIPID BIOSURFACTANTS}

Mayri A. Diaz ${ }^{1 *}$, Isora Urdaneta de Ranson ${ }^{2}$, Blas Dorta Dorta ${ }^{2}$, Ibrahim M. Banat ${ }^{1}$, Maria L. Blazquez $^{3}$, Felisa Gonzalez ${ }^{3}$, Jesús A. Muñoz ${ }^{3}$, Antonio Ballester ${ }^{3}$.

1. School of Biomedical Sciences, Faculty of Life \& Health Sciences, University of Ulster, BT52 1SA, Northern Ireland, UK.

2. Laboratorio de Procesos Fermentativos, Instituto de Biología Experimental, Facultad de Ciencias, Universidad Central De Venezuela, 1010A, Caracas-Venezuela.

3. Departamento de Ciencia de Materiales e Ingeniería Metalúrgica, Facultad de Ciencias Químicas, Universidad Complutense de Madrid, 28040 Madrid-Spain.

* Corresponding author:

Mayri A. Diaz De R.

School of Biomedical Sciences

Faculty of Life \& Health Sciences

University of Ulster

BT52 1SA

Northern Ireland, UK

Tel. +44 2870123062

E-mail: mayri.diazderienzo@manchester.ac.uk 


\title{
ACCEPTED MANUSCRIPT
}

\begin{abstract}
The use of surfactants as a method for solubilisation and removal of heavy metal contamination from soil has been reported before. Biosurfactants produced by some microorganisms are able to modify the surface of various metals and aggregate on interphases favouring metal separation process from contaminated environments. We evaluated the feasibility of enhancing the removal of metal ions from a mineral waste/contaminated soils using alternate cycles of treatment with rhamnolipid biosurfactants and bioleaching with amixed bacterial culture of Acidithiobacillus thiooxidans and Acidithiobacillus ferrooxidans. Bioleaching alone removed 50\% Zn and 19\% Fe. When rhamnolipids was used at low concentration $(0.4 \mathrm{mg} / \mathrm{mL}) 11 \% \mathrm{Fe}$ and $25 \% \mathrm{Zn}$ were removed while at $1 \mathrm{mg} / \mathrm{mL} 19 \% \mathrm{Fe}$ and $52 \% \mathrm{Zn}$ removal were achieved. When using a cyclic treatment combining bioleaching and biosurfactants, metal removal reached up to $36 \%$ for $\mathrm{Fe}$ and $63 \%$ to $70 \%$ for $\mathrm{Zn}$.
\end{abstract}

Key words: Metal removal, bioleaching, soil washing, rhamnolipids, Pseudomonas aeruginosa 


\section{ACCEPTED MANUSCRIPT}

\section{INTRODUCTION}

Waste from metal ore mining processes is one of the largest streams with potential environmental impact which has left a historical legacy of contaminated land. High metal content as well as the associated toxicity represents a great risk for ecosystems and human health. This kind of residue often contains sulphide minerals such as pyrite $\left(\mathrm{FeS}_{2}\right)$ which oxidizes in the presence of air and water producing iron and sulphate in solution and which ultimately leads to acidic conditions in the waste stream medium and acid mine drainage and associated environmental contamination affecting both surface and ground water (Akcil and Koldas, 2006). In addition, mining residues tend to modify contaminated soils changing their intrinsic properties producing several effects, such as: imbalance of essential nutrient content, disruption of biogeochemical cycles, low exchange capacity or low water retention (Puga et al., 2006). The presence of metals such as arsenic, cadmium, zinc, copper, chromium, manganese, mercury, lead and even cyanide species have confirmed detrimental effects on the chemical quality of soils (Alloway, 1995; Pinochet et al., 2002).

Some technologies used in the remediation of metal contaminated soils are based on physical separation (gravity concentration, magnetic separation or electrostatic separation) or chemical extraction (acid or chelate extraction). The use of microorganisms for metal extraction, known as bioleaching, has been investigated for a long time. The mechanisms involved describe different redox reactions mediated by enzymatic processes. Different strains of Acidithiobacillus have been reported for their ability to leach base metals such as iron, copper and zinc (Rodríguez et al., 2003). 


\section{ACCEPTED MANUSCRIPT}

Extraction of metals by surfactants thought solubilisation has been known and previously applied with effective results (Stalikas, 2002). Both cationic and anionic surfactants have been used as washing or flushing agents to extract metals from aqueous solutions by counterion binding (Mulligan and Wang, 2006; Wang et al., 2004) without involving any direct or indirect mechanism of bioleaching.

Rhamnolipids are surfactants of biological origin commonly produced by strains of the genus Pseudomonas. Their amphiphilic structure allows them to partition on interphases increase the bioavailability and or mobilisation of hydrophobic substrates (Banat et al. 2010). Based on their surface activity, rhamnolipids can be used in many industries as emulsifiers, foaming or dispersing agents (Marchant and Banat, 2012a,b). At present special attention are directed towards environmental applications in which their properties could be useful for the development of physicochemical and biological remediation technologies (Pacwa-Plociniczak et al., 2011). These compounds may form complexes with metals thus facilitating their desorption from contaminated soils particles and leading to a better bioavailability in the aqueous phase. This approach would allow the subsequent extraction and recovery of these metals improving the environmental conditions on the site. Biosurfactants' ability to reduce the interfacial tension allows direct contact with the adsorbed metals. Consequently, cationic metals could be removed from soils by flushing through with anionic biosurfactants such as rhamnolipids. Comparative studies using different types of surfactants have demonstrated the effectiveness of rhamnolipids in the removal of $\mathrm{Zn}, \mathrm{Cu}, \mathrm{Pb}$ and $\mathrm{Cd}$ from a soil exposed to metal deposition (Slizovskiy et al., 2011). 


\section{ACCEPTED MANUSCRIPT}

Most studies undertaken so far have focused on the use of surfactants/biosurfactant only as a mechanism for dissolving metals through washing system, or either the use of bacteria using the bioleaching process. In this study we evaluate the feasibility to enhance metal removal from a mineral waste using an alternate cycle of two different treatments: with a biosurfactant obtained from a Pseudomonas aeruginosa strain and with a bioleaching process using a mixed culture of bacteria belonging to the genus Acidithiobacillus. Our model makes use of surfactant as a facilitator for the separation of metal from the contaminated soil, opening a way for the bioleaching mechanism, using the synergy between two processes demonstrating the effectiveness of the model.

\section{MATERIALS AND METHODS}

\section{Sampling site}

The samples for the microbial study were collected from an old closed mine site named "Brunita" near Llano del Beal (Sierra Cartagena-La Unión, Murcia, Spain) and formerly used as a source of $\mathrm{Pb}-\mathrm{Zn}$ ores. The soil samples were dried at room temperature and subsequently the material was sieved through a $1 \mathrm{~mm}$ sieve and particles $>1 \mathrm{~mm}$ were discarded. The small particles $(<1 \mathrm{~mm})$ met the requirements for assessment of soil by sequential extraction technique (Brady et al., 1999) and were characterized physically, chemically and mineralogically to be used in the different studies.

\section{Physical characterization of the contaminated soil}

The contaminated soil (CS) were homogenized and divided into portions of about $2 \mathrm{~kg}$ and kept in plastic bags in a refrigerator at $-4^{\circ} \mathrm{C}$. Samples preparation for the various assays was carried out according to ASTM C702. The particle size distribution was determined using the Tyler 


\section{ACCEPTED MANUSCRIPT}

sieve series mesh size of $1000,750,600,430,250$ and $100 \mu \mathrm{m}$. The bulk density was determined by measuring the volume occupied by a given mass of dry soil in a container of known dimensions. While specific density was obtained by calculating the specific volume occupied by a known mass of ground in a known density liquid (deionized water) using a pycnometer.

\section{Chemical characterization of the contaminated soil}

Soil $\mathrm{pH}$, redox potential, and the concentration of potentially contaminating metals $(\mathrm{Fe}, \mathrm{Cu}, \mathrm{Zn}$, $\mathrm{Pb}$ ) were carried out. The $\mathrm{pH}$ and redox potential of the soil was determined with two contact media: deionized water of $\mathrm{pH} 5.6$ and nutrient medium $0 \mathrm{~K}$ of $\mathrm{pH} 1.8$. For this, $10 \mathrm{~g}$ of soil and $90 \mathrm{~mL}$ of liquid media were placed in a $250 \mathrm{~mL}$ Erlenmeyer flask with constant stirring at 150rpm. $\mathrm{pH}$ and redox potential of the suspensionwere measured after 1, 22 and 120h, with a $\mathrm{Ag} / \mathrm{AgCl}$ and a platinum electrode, respectively, in a pH meter Crison Basic model 20 (Rayment et al., 2006). In the same way $10 \mathrm{~g}$ of soil and $90 \mathrm{~mL}$ of deionized water were placed together and $\mathrm{pH}$ was determinated. The availability of metals from different soil was determined by sequential extraction according to Brady et al. (1999) (Figure 1).

\section{Mineralogical characterization of the contaminated soil}

Mineralogical characterization was carried out by powder X-ray diffraction (XRD) on a Phillips

X'pert-MPD system using $\mathrm{Cu}-\mathrm{K} \alpha=1.5406 \AA$. The scanning range was from $10^{\circ}$ to $70^{\circ} 2 \theta$ with an angular interval of $0.05^{\circ}$ and $4 \mathrm{~s}$ counting time. The crystalline phases were identified using standard cards from the International Centre for Diffraction Data (ICDD, Newtown Square, Pennsylvania) Powder Diffraction File database. 


\section{ACCEPTED MANUSCRIPT}

\section{Bacterial cultures}

A mesophilic mixed culture of Fe- and S-oxidizing microorganisms (Acidithiobacillus thiooxidans and Acidithiobacillus ferrooxidans) was provided by the Department of Materials Science and Metallurgical Engineering, Complutense University of Madrid, Spain. The bacterial culture was grown at $30^{\circ} \mathrm{C}$ on $0 \mathrm{~K}$ medium $\left(3 \mathrm{~g} / \mathrm{L}\left(\mathrm{NH}_{4}\right)_{2} \mathrm{SO}_{4}, 0.1 \mathrm{~g} / \mathrm{L} \quad \mathrm{K}_{2} \mathrm{HPO}_{4}, 0.5 \mathrm{~g} / \mathrm{L}\right.$ $\mathrm{MgSO}_{4} \cdot 7 \mathrm{H}_{2} \mathrm{O}, 0.1 \mathrm{~g} / \mathrm{L} \mathrm{KCl}$, and $\left.0.013 \mathrm{~g} / \mathrm{L} \mathrm{Ca}\left(\mathrm{NO}_{3}\right)_{2} \cdot 4 \mathrm{H}_{2} \mathrm{O}\right)$, in a $250 \mathrm{~mL}$ flask at $200 \mathrm{rpm}, \mathrm{pH}$ 1.7 .

Rhamnolipids (Rhl's) were produced from a strain of Pseudomonas aeruginosa CVCM 411 provided by the Venezuelan Central Collection of Microorganisms. The culture was grown in $250 \mathrm{~mL}$ flasks, at $200 \mathrm{rpm}$ and $37^{\circ} \mathrm{C}$ on PPGAS medium $\left(0.02 \mathrm{M} \mathrm{NH}_{4} \mathrm{Cl}, 0.02 \mathrm{M} \mathrm{KCl}, 0.12 \mathrm{M}\right.$ tris$\mathrm{HCl}, 1 \%$ peptone and $\mathrm{MgSO}_{4} \cdot 7 \mathrm{H}_{2} \mathrm{O} 0.01 \%$ ) at $\mathrm{pH}=7.4$, for $72 \mathrm{~h}$. Rhamnolipids were collected from solution following the method proposed by Dèziel et al. (1999) and then stored at $4^{\circ} \mathrm{C}$ until use.

\section{Microcosm tests}

The microcosms were prepared in $250 \mathrm{~mL}$ Erlenmeyer flasks containing $10 \mathrm{~g}$ of sterilized contaminated soil, $90 \mathrm{~mL}$ of $0 \mathrm{~K}$ medium $(\mathrm{pH} 1.7)$ and $10 \mathrm{~mL}$ of a cell suspension which was withdrawn from stocks of mixed cultures of $\mathrm{Fe}$ - and S-oxidizing bacteria in exponential growth phase ( $>10^{8}$ cell/mL). Tests were carried out in triplicate (with yield differences lower than $5 \%$ ), in an incubator at $30^{\circ} \mathrm{C}$ and $150 \mathrm{rpm}$ (Rodríguez et al., 2003). A sample of $2 \mathrm{~mL}$ was removed from solution after 7, 14, 21, 28, 35, 42 days and analysed for metal content (Fe and $\mathrm{Zn}$ ).. The solid residues were dried and analysed following a sequential extraction procedure. Control test 


\section{ACCEPTED MANUSCRIPT}

was carried out in the presence of water without the mixed culture of Fe- and S-oxidizing bacteria.

\section{Washing tests}

The contaminated soils were washed with rhamnolipids simulating spot removal techniques. Biosurfactants solutions (original stock $0.1 \% \mathrm{v} / \mathrm{v}$ ) were placed in a $500 \mathrm{~mL}$ flask at two different concentrations $(0.4$ and $1 \mathrm{mg} / \mathrm{mL})$. Both tests contained $10 \mathrm{~g}$ of sterelized contaminated soil in $0 \mathrm{~K}$ medium at $\mathrm{pH} 8$ for a final volume of $100 \mathrm{~mL}$. Washing tests were run according to the protocol described by Mulligan et al. (2001) with slight modifications (30 h, $150 \mathrm{rpm}$ and $\left.25^{\circ} \mathrm{C}\right)$. A sample of $2 \mathrm{~mL}$ was removed after $0.25,1,3$ and $30 \mathrm{~h}$ to determine the percentage of iron and zinc leached. The solid residues were dried and analysed following a sequential extraction procedure.

Additional washing tests were carried out with the highest concentration of rhamnolipids (1 $\mathrm{mg} / \mathrm{mL}$ ) in $0 \mathrm{~K}$ medium at $\mathrm{pH} 8$ for $30 \mathrm{~h}$. After that time, the contents were centrifuged at $10,000 \mathrm{~g}$ for $15 \mathrm{~min}$ and the supernatant was used to determine the concentration of metals removed. The residue was then collected, dried and placed in contact with a mixed bacterial culture for 21 days according to the experimental procedure described in the microcosm tests.

\section{Cyclic treatment}

This experimentation consisted of alternate treatment cycles of washing (Rhl's), microcosm (mixed culture), washing (Rhl's), to complete a period of time of 25 days (Figure 2).

The first cycle was started under the experimental conditions referred in the washing tests. After $24 \mathrm{~h}$, the entire volume was centrifuged at $10,000 \mathrm{~g}$ for $15 \mathrm{~min}$ and the supernatant used to determine the concentration of metals leached. The solid residue was dried and placed in contact 


\section{ACCEPTED MANUSCRIPT}

with the mixed bacterial culture suspended in $0 \mathrm{~K}$ medium $(100 \mathrm{~mL})$ under the experimental conditions described in the microcosm tests.

After 7 days of incubation, the total volume was centrifuged at $10,000 \mathrm{~g}$ following the same procedure as before. The concentration of metals removed was evaluated in the supernatant and the residue of the bacterial treatment was dried and used in washing tests. Again, after $24 \mathrm{~h}$, the supernatant obtained by centrifugation was analysed for metal content. This alternate treatment was repeated for a period of 25 days.

RESULTS AND DISCUSSION

\section{Characterization of Contaminated Soil (CS)}

\section{Physical characterization}

One of the soil primary functions is the regulation of the water flow in the hydrological system. Two parameters that determine the degree of permeability of the soil are its particle size and its density. The particle size distribution of the contaminated soil under study is depicted in Figure 3 and shows that it mainly contains fine particles, $80 \%$ by weight having a size less than 250 microns. Such size distribution suggests the presence of weathering products coming from mining-metallurgical waste with a fine particle size and as suggested later containing jarosite as the main component identified by XRD. Consequently, the lower permeability of the CS would result in an increase of water retention, a key element in the biogeochemical transformations of metal sulphides. Soil density can be obtained under two criteria as specific or bulk density. Accordingly, the specific density of a soil tends to be greater than its bulk density (Brady and 


\section{ACCEPTED MANUSCRIPT}

Weil, 2008). In this regard, the higher specific gravity of the contaminated soil (Table 1) may be attributed to the presence of mining residues, most likely the metallic sulphides.

\section{Chemical Characterization}

CS was characterized from representative samples that were analysed for $\mathrm{pH}$ and redox potential in contact with a liquid medium and the metal content. Redox potential and $\mathrm{pH}$ are two variables that govern the retention and/or mobilization of metals in soils (Plant and Raiswell, 1983; Alloway and Ayres, 1993). Measurements in $\mathrm{pH}$ showed a significant drop in deionized water, from 6.11 to 2.41 , while in in the medium $0 \mathrm{~K}$ slight increase from 1.85 to 2.37 . This is a consequence of the strong acidic composition of the CS, which is reflected in the trend of a single $\mathrm{pH}$ value after 5 days of contact between the $\mathrm{CS}$ and both liquid media. The high acidity of CS would result in the dissolution of the mineral phases with buffering capacity, such as carbonates and hydroxides. Hence, this would have a detrimental effect on the cation exchange capacity of this soil (Konhauser, 2007; Martín et al., 2007; Brady and Weil, 2008).

The redox potential of the CS in deionized water and $0 \mathrm{~K}$ medium suggests that this soil has oxidizing properties that, similar to $\mathrm{pH}$, promotes metal mobilization (Sharpe, 1993). Therefore, the values of $\mathrm{pH}$ and redox potential recorded during these trials are indicatives that the contaminated soil could promote the growth of acidophilic and autotrophic bacteria, such as Acidithiobacillus spp., which play a key role in the mobilization of toxic metals (Holt et al., 1994; Ballester et al., 2000). 


\section{ACCEPTED MANUSCRIPT}

\section{Metal content and bioavailability in CS}

The determination of metal content in CS by sequential extraction was carried out in triplicate on representative samples. A widely used parameter for the declaration of contamination of soils is metal concentration. The choice of metallic elements to be evaluated in this study was conducted on the basis of their relative abundance in the sample and in accordance with data previously reported (García et al., 2007; Robles -Arenas et al., 2006). The total concentration of metals (Fe, $\mathrm{Cu}, \mathrm{Zn}$ and $\mathrm{Pb}$ ) in the $\mathrm{CS}$ is shown in Table 2. The values for $\mathrm{Pb}$ and $\mathrm{Zn}$ were 7 and 5 times greater than the limit values set by the CMJA (Andalusian Ministry of the Environment) for $\mathrm{Pb}$ and $\mathrm{Zn}$, respectively.

\section{Mineralogical characterization}

In most soils, metals are present as carbonates, oxides, sulphides or salts. While the dominant minerals of each metal can vary from one soil to another, neither of these minerals can selfregulate the metal concentration in the aqueous phase of the soil (Brady and Weil, 2008). According to the characteristics of mining-metallurgical activities developed in the sampling area of the CS in the Sierra Cartagena-La Union, it is expected that soil pollution is associated with sulphidic material present in its mineral composition (García et al., 2007; Robles-Arenas et al., 2006). In this sense, the determination of the principal mineral phases in the CS was performed on powdered samples of the original soil. The XRD pattern for the contaminated soil showed oxidized phases (quartz, silicates and sulphates -gypsum and plumbojarosite-) as major constituents and to a lesser extent iron sulphides (pyrite). However, the significant presence of zinc recorded by sequential extraction (Table 2) was not confirmed in XRD analysis of the raw 


\section{ACCEPTED MANUSCRIPT}

CS. This could be attributed to zinc be forming an amorphous compound or adsorption to the soil.

\section{Microcosm tests}

The results obtained in the microcosm at $30^{\circ} \mathrm{C}$ are shown in Figure 4 . Both iron and zinc in solution increased over time. The leaching of metal sulphides is usually accompanied by an increase in metal concentration in the leachate (Bosecker, 1997). It is well known that the dissolution of pyrite by ferric sulphate leads to ferrous sulphate as observed in reaction [1]. In turn, Fe-oxidizing microorganisms are able to catalyse the oxidation of ferrous into ferric sulphate, either in its ionic (reaction [2]) or molecular form (reaction [3]) (Jensen and Webb, 1995; Acevedo and Gentina, 2005). Pyrite is not dissolved in acidic solutions but attacked exclusively by an oxidizing agent such as $\mathrm{Fe}^{3+}$. The presence of Fe-oxidizing bacteria would therefore be necessary to regenerate the oxidizing agent required for leaching:

$$
\begin{aligned}
& \mathrm{FeS}_{2}+14 \mathrm{Fe}^{3+}+8 \mathrm{H}_{2} \mathrm{O} \rightarrow 15 \mathrm{Fe}^{2+}+16 \mathrm{H}^{+}+2 \mathrm{SO}_{4}{ }^{2-} \\
& 2 \mathrm{Fe}^{2+}+1 / 2 \mathrm{O}_{2}+2 \mathrm{H}^{+} \stackrel{\text { Bacteria }}{\longrightarrow} 2 \mathrm{Fe}^{3+}+\mathrm{H}_{2} \mathrm{O} \\
& \mathrm{FeSO}_{4}+\mathrm{H}_{2} \mathrm{SO}_{4}+1 / 2 \mathrm{O}_{2} \stackrel{\text { Bacteria }}{\longrightarrow} \mathrm{Fe}_{2}\left(\mathrm{SO}_{4}\right)_{3}+\mathrm{H}_{2} \mathrm{O}
\end{aligned}
$$

On the other hand, the leaching rate for zinc is much faster than that for iron (Figure 4) and also resulting in higher final metal extractions $(50 \% \mathrm{Zn}$ vs. $19 \% \mathrm{Fe})$. This is likely due to zinc sulphides being more soluble in acidic conditions than pyrite and its ability to dissolved by oxidizing agents such as ferric iron(Acevedo and Gentina, 2005): 


\section{ACCEPTED MANUSCRIPT}

$\mathrm{ZnS}+\mathrm{Fe}_{2}\left(\mathrm{SO}_{4}\right)_{3} \rightarrow \mathrm{ZnSO}_{4}+\mathrm{S}^{0}+2 \mathrm{FeSO}_{4}$

$\mathrm{ZnS}+2 \mathrm{H}^{+} \rightarrow \mathrm{Zn}^{2+}+\mathrm{H}_{2} \mathrm{~S}$

The presence of $\mathrm{Fe}(\mathrm{III})$ in solution accounts for the pyrite dissolution, a process that generates a great amount of $\mathrm{Fe}(\mathrm{II})$ that can be oxidized by bacteria to $\mathrm{Fe}(\mathrm{III})$ (Rodríguez et al., 2003). Previous studies have shown that the bioleaching of complex metallic sulphides with mesophilic mixed cultures of the genus Acidithiobacillus yields high zinc extractions (around 90\%), as shown in reactions [4] and [5] (Deveci et al., 2004; Wang et al., 2004).

\section{Washing tests}

Washing experiments were performed at $\mathrm{pH} 8$ and at two different rhamnolipid concentrations (Figure 5). The amount of iron leached in the presence of $1 \mathrm{mg} / \mathrm{mL}$ of Rhl's was comparatively higher than with $0.4 \mathrm{mg} / \mathrm{mL}$ of the same surfactant (19\% vs. $11 \%$, respectively). In the case of zinc, a similar trend was observed after 30h of washing: $52 \%$ of $\mathrm{Zn}$ was dissolved in the presence of $1 \mathrm{mg} / \mathrm{mL}$ of RhL's compared with $25 \%$ of $\mathrm{Zn}$ with $0.4 \mathrm{mg} / \mathrm{mL}$ of Rhl's (Figure 5). These results confirm previous reports by Mulligan and Wang (2006). The residues obtained were analysed to determine the distribution of iron and zinc after washing. It was expected a greater transformation of iron from the sulphide fraction than from any other fraction, releasing $\mathrm{Fe}^{3+}$ as expected in reactions [1] and [2] (Jensen and Webb, 1995). Consequently, the decrease of iron in the sulphide fraction detected in the microcosms (as shown in Table 3) was attributable to the washing step mediated by the presence of rhamnolipids.

Under our experimental conditions rhamnolipids biosurfactant stimulated a preferential dissolution of iron from the sulphide fraction that affected its final distribution in different soil 


\section{ACCEPTED MANUSCRIPT}

fractions. Unlike iron, which showed a higher concentration in the sulphide and residual phases in the contaminated soil, zinc was more concentrated in the exchangeable and sulphide phases followed by the hydroxide and carbonate phases (Table 3).

According to Table 3, the significant decrease in the exchangeable and carbonate phases could be attributable to a higher bioavailability of toxic metals from these fractions. Metals in the exchangeable fraction are weakly adsorbed by electrostatic interactions and are easily available in natural environments ( $\mathrm{Li}$ et al., 2001). On the other hand, mobilization of metals from the carbonate phase is favoured by $\mathrm{pH}$ changes caused by different environmental agents (Gleyzes et al., 2002). Finally, the availability of zinc in the sulphide fraction may be affected by the formation of a diffusive layer of elemental sulphur on the sulphide surface (Rodríguez et al., 2003).

The microcosm tests to which bacterial cultures were added showed that iron and zinc could be leached from the soil up to $19 \%$ and 50\%, respectively. Similar results (19\% Fe and 52\% Zn) were obtained in the washing tests but only after $24 \mathrm{~h}$ and $\mathrm{pH}$ 8.0. In the latter case, after $24 \mathrm{~h}$ of washing with $1 \mathrm{mg} / \mathrm{mL}$ rhamnolipids followed by 21 days of contact with an oxidizing bacterial mixed culture, a $25 \%$ of iron recovery was achieved (Table 4). For tests that started with the mixed culture followed by a washing step, a final iron extraction of $22 \%$ was obtained (Table 5). In both cases, the increase in the iron recovery is an indication that the use of oxidizing bacteria in combination with rhamnolipids improves the removal of iron from the contaminated soil. 


\section{ACCEPTED MANUSCRIPT}

\section{Cyclic treatment}

The cyclic treatment tests were designed to increase performance of the removal of heavy metals from the contaminated soil. When using alternate cycles of bioleaching and washing tests and a frequency of 6 days between Fe- and S-oxidizing bacteria and rhamnolipids, the percentage of iron in the aqueous phase increased up to $36 \%$ (Table 6). For zinc, the improvement was noticeable reaching a final zinc recovery of $70 \%$. The increase in the removal of both metals is attributable to a joint action of bacterial activity from the mixed culture and the washing effect of rhamnolipids. When this effect is repeated several times, under the right conditions, it is possible to increase metal removal from contaminated soils and promote a phase change of each metal after both treatments (bioleaching and washing).

The results obtained indicate that it is possible to achieve significant removal of metals such as iron and zinc from a mining waste using a mixed population of Acidithiobacillus thiooxidans and Acidithiobacillus ferrooxidans. Such removal can be enhanced by a previous washing step with rhamnolipids biosurfactants in solution at $\mathrm{pH} 8$. Rhamnolipids form micelles at $\mathrm{pH} 6.8$ with molecules charged negatively while their surface activities increase at higher $\mathrm{pH} 7.0$ and 7.5 (Mulligan and Wang, 2006). Consequently, the effectiveness of rhamnolipids for metal separation can be greatly affected by $\mathrm{pH}$ change. An optimum desorption of $\mathrm{Cd}$ (II) and $\mathrm{Zn}$ (II) from quartz in the presence of rhamnolipid biosurfactants was reported to occur at $\mathrm{pH} 6.8$ by Mulligan and Wang (2006).

Oxidizing bacteria participate via an indirect bioleaching mechanism through to the regeneration of the oxidizing agent $\left(\mathrm{Fe}^{3+}\right)$ while the role played by the rhamnolipids can be related to the complexation and micelle formation with metal ions adsorbed on mineral surfaces. During this 


\section{ACCEPTED MANUSCRIPT}

process, metal distribution between the different soil fractions is remarkably modified, especially the removal of zinc from the exchangeable and sulphide fractions. The ability to wash such contaminated soils to remove heavy metals may have some application in future process for removal and or recovery of such metals for contaminated environments.

\section{CONCLUSIONS}

This work demonstrates that a combined strategy may be a possible way for the treatment of heavy metal contaminated soil exposed to acid mine drainage. This is possible to achieve using a process involving washing with mixed bacterial population of Acidithiobacillus thiooxidans and Acidithiobacillus ferrooxidans, in combination with surface active molecules. The use of cycles in such washing process has to be optimized for future work in terms of energy costs, residence time and possible recovery of such metals. 


\section{ACCEPTED MANUSCRIPT}

\section{REFERENCES}

Acevedo, F. and Gentina, J. 2005. Fundamentos y perspectivas de las tecnologías biomineras. Valparaíso, Chile: ISBN 956-17-0373-4. Ediciones Universitarias de Valparaíso, Pontificia Universidad Católica de Valparaíso.

Akcil, A. and Koldas, S. 2006. Acid mine drainage (AMD): causes, treatment and case studies. $J$. Clean. Prod. 14, 1139-1145.

Alloway, B.J. and Ayres D. 1993. Chemical Principles of Environmental Pollution. Blackie Academic \& Professional. London.

Alloway, B.J. 1995. Heavy metals in soils. Blackie Academic \& Professional. London.

Ballester, A., Verdeja, L. and Sancho, J. 2000. In: Metalurgia Extractiva Fundamentos. Madrid, Spain.

Banat I.M., Franzetti A., Gandolfi I., Bestetti G., Martinotti M.G., Fracchia L., Smyth T. J. and Marchant R. 2010. Microbial biosurfactants production, applications and future potential. Appl. Microbiol. Biot. 87,427-444.

Bosecker, K. 1997. Bioleaching: metal solubilization by microorganisms. FEMS Microbiol. Rev. 20, 591-604.

Brady, P., Spalding, B., Krupa, K., Waters, R., Zhang, P., Boms, D. and Brady, W. 1999. Site Screening and Technical Guidance for Monitored Natural Attenuation at DOE Sites. Sandia Report, SAND99-0464.

Brady, N. and Weil, R. 2008. The nature and properties of soils, 14th Ed. Pearson Prentice Hall. Upper Saddle River, New Jersey, USA. 


\section{ACCEPTED MANUSCRIPT}

Deveci, H., Akcil, A. and Alp, I. 2004. Bioleaching of complex zinc using mesophilic and thermophilic bacteria: comparative importance of $\mathrm{pH}$ and iron. Hydrometallurgy 73, 293-303.

Dèziel, E., Lepine, F., Dennie, D., Boismenu, F., Mamer, O. and Villemur, R. 1999. Liquid chromatography/mass spectrometry analysis of mixtures of rhamnolipids produced by Pseudomonas aeruginosa 57RP grown on mannitol or naphthalene. Biochim. Biophys. Acta 1440, 244-252.

García, C., Ballester, A., Gonzalez, F. and Blazquez, M. 2007. Microbial activity in weathering columns. J.Hazard.Mater. 141, 565-574.

Gleyzes, C., Tellier, S. and Astruc, M. 2002. Fractionation studies of trace elements in contaminated soils and contaminated soils: a review of sequential extraction procedures. Trends Anal. Chem. 21, 451-467.

Holt, J., Krieg, N., Sneath, P., Staley, J. and Williams, S. 1994. Bergey's manual of determinative bacteriology. Williams \& Wilkins, Baltimore, USA.

Jensen, A. and Webb, C. 1995. Ferrous sulphate oxidation using Thiobacillus ferrooxidans: a review. Process Biochem. 30 (3), 225-236.

Konhauser, K. 2007. Introduction to geomicrobiology. Blackwell Publishing, 350 Main Street, Malden, MA, USA.

Li, B., Wang, Q., Huang, B. and Li, S. 2001. Evaluation of the results from a quasi-Tessier's sequential extraction procedure for heavy metal speciation in soils and contaminated soil by ICPMS. Anal. Sci. 17, 1561-1564.

Marchant, R., and Banat, I.M. 2012a. Biosurfactants: a sustainable replacement for chemical surfactants? Biotechnol. Lett. 34, 1597-1605. 


\section{ACCEPTED MANUSCRIPT}

Marchant, R., and Banat, I.M. 2012b. Microbial biosurfactants: challenges and opportunities for future exploitation. Trends Biotechnol. 30 (11), 558-565.

Martín, F., Diez, M., García, I., Simón, M., Dorronsoro, C., Iriarte, A. and Aguilar, J. 2007. Weathering of primary minerals and mobility of major elements in soils affected by an accidental spill of pyrite tailing. Sci.Total Environ.378,49-52.

Mulligan, C., Yong, R. and Gibbs, B. 2001. Surfactant remediation contaminated soil: a review. Eng. Geol. 60, 371-380.

Mulligan, C. and Wang, S. 2006. Remediation of heavy metals contaminated soil by a rhamnolipid foam. Eng. Geol. 85, 75-81.

Pacwa-Plociniczak, M.; Plaza, G., Piotrowska-Seget, Z. and Cameotra, S. 2011. Environmental applications of biosurfactants: recent advances. Int. J. Mol. Sci. 12, 633-54.

Pinochet, D., Aguirre, J. and Quiroz, E. 2002. Estudio de la lixiviación de cadmio, mercurio y plomo en suelos derivados de cenizas volcánicas. Agro Sur. 30, 51-58.

Plant, J. and Raiswell, R. 1983. Applied Environmental Geochemistry: Principles of Environmental Geochemistry. Academic Press, London. UK.

Puga, S., Sosa, M., Lebgue, T., Quintana, C. and Campos, A. 2006. Contaminación por metales pesados en suelo provocada por la industria minera. Ecología Aplicada 5, 149-155.

Rayment, G., Sadler, R., Craig, A., Noller, B. and Chiswell, B. 2006. Analysis of inorganic parameters: Chemical analysis of contaminated land. Blackwell Publishing. CRC Press Oxford, UK. 


\section{ACCEPTED MANUSCRIPT}

Robles-Arenas, V., Rodríguez, R., García, C., Manteca, J. and Candela, L. 2006. Sulphidemining impacts in the physical environment: Sierra de Cartagena-La Unión (SE Spain). Case study. Environ. Geol. 51, 47-64.

Rodríguez, Y., Ballester, A., Blázquez, M.L., González, F. and Muñoz, J.A. 2003. New information on the pyrite bioleaching mechanism at low and high temperature. Hydrometallurgy 71, 37-46.

Rossi, G. 1990. Biohydrometallurgy. McGraw-Hill, Hamburg, Germany.

Sand, W., Gehrke, T., Hallmann, R. and Schippers, A. 1995. Sulfur chemistry, biofilm, and the (in)direct attack mechanism-a critical evaluation of bacterial leaching. Appl. Microbiol. Biotechnol. 43, 961-966.

Sharpe, A. 1993. Química inorgánica. Reverté, Loreto, Barcelona. Spain.

Slizovskiy, I., Kelsey, J. and Hatzinger, P. 2011. Surfactant-facilitated remediation of metalcontaminated soils: efficacy and toxicological consequences to earthworms. Environ. Toxicol. Chem. 30, 112-123.

Stalikas, C. 2002. Micelle-mediated extraction as a tool for separation and preconcentration in metal analysis. Trends Anal. Chem. 21, 343-355.

Wang, J., Qiu, G., Qin, W. and Zhang, Y. 2004. Microbial leaching of marmatite by Acidithiobacillus ferrooxidans and Acidithiobacillus thiooxidans. Nonferr. Metal. Soc. 16, 937942. 


\section{ACCEPTED MANUSCRIPT}

Table 1. Specific and bulk densities $(\rho)$ for the contaminated soil.

\begin{tabular}{lcc}
\hline Sample & $\rho_{\text {specific }\left(\mathrm{g} / \mathrm{cm}^{3}\right)}$ & $\rho_{\text {bulk }\left(\mathrm{g} / \mathrm{cm}^{3}\right)}$ \\
\hline Contaminated Soil $(\mathrm{CS})$ & 2.98 & 1.12
\end{tabular}

Contaminated Soil (CS)

2.98

1.12

Table 2. Distribution of metals in the different fractions of the contaminated soil.

\begin{tabular}{lcccc}
\hline Soil fraction & $\mathbf{m g ~ F e} / \mathbf{K g ~ C S}$ & $\mathbf{m g ~ C u} / \mathbf{K g ~ C S}$ & $\mathbf{~ m g ~ Z n / K g ~ C S}$ & $\mathbf{~ m g ~ P b / K g ~ C S}$ \\
\hline Exchangeable & 2587.09 & 28.34 & $1,538.27$ & 347.00 \\
Organic & 7.06 & 10.82 & 6.02 & 25.04 \\
Carbonates & 45.98 & 4.00 & 59.44 & 198.71 \\
Hydroxides & 847.66 & 5.10 & 39.09 & 33.98 \\
Sulphides & $278,812.39$ & 116.92 & $3,363.07$ & $12,896.60$ \\
Residual & $13,476.15$ & 37.06 & 724.05 & $4,464.42$
\end{tabular}

Table 3. Content of $\mathrm{Zn}$ and $\mathrm{Fe}$ in each contaminated soil fraction after 30h of washing with two different concentrations of rhamnolipids (A: $0.4 \mathrm{mg} / \mathrm{mL}$; B: $1 \mathrm{mg} / \mathrm{mL}$ ). The control test is referred as $\mathrm{mgZn} / \mathrm{Kg} \mathrm{CS}$ and $\mathrm{mgFe} / \mathrm{Kg} \mathrm{CS}$.

\begin{tabular}{|c|c|c|c|c|c|c|}
\hline Soil fraction & mg Zn/Kg CS & mg Zn A/KgCS & mg Zn B/Kg CS & $\mathrm{mg} \mathrm{Fe} / \mathrm{Kg} \mathrm{CS}$ & mg Fe A/Kg CS & mg Fe B/Kg CS \\
\hline Exchangeable & 268,510 & 145,110 & 124,350 & 8,680 & 5,150 & 5,550 \\
\hline Organic & 1,050 & 440 & 260 & 20 & 0.00 & 20 \\
\hline Carbonate & 9,780 & 3,060 & 2,180 & 150 & 110 & 140 \\
\hline Hydroxide & 6,810 & 1,750 & 870 & 2,840 & 850 & 700 \\
\hline Sulphide & 587,120 & 296,790 & 156,800 & 935,610 & 754,500 & 642,820 \\
\hline
\end{tabular}




\section{ACCEPTED MANUSCRIPT}

Table 4. Percentage of Fe and $\mathrm{Zn}$ dissolved after $24 \mathrm{~h}$ of washing with $1 \mathrm{mg} / \mathrm{mL}$ of rhamnolipids ( $\mathrm{v} / \mathrm{v})$ followed by 20 days of contact with a mixed culture of A. thiooxidans and A. ferrooxidans.

\begin{tabular}{|c|c|c|c|}
\hline Treatment & Time (days) & \% Fe leached & \% Zn leached \\
\hline Rhl's & 1 & 18.45 & 57.00 \\
\hline Bac & 20 & 6.76 & 6.00 \\
\cline { 3 - 4 } & \% Total Leachate & $\mathbf{2 5 . 2 1 \pm 0 . 8 1}$ & $\mathbf{6 3 \pm 0 . 3 5}$ \\
\cline { 2 - 4 } & &
\end{tabular}

Rhl's = rhamnolipids solution

$\mathrm{Bac}=$ Bacteria culture

Table 5. Percentage of $\mathrm{Fe}$ and $\mathrm{Zn}$ dissolved after 20 days of bioleaching with a mixed culture of A. thiooxidans and A. ferrooxidans followed by $24 \mathrm{~h}$ of washing with $1 \mathrm{mg} / \mathrm{mL}$ of rhamnolipids.

\begin{tabular}{|c|c|c|c|}
\hline Treatment & Time (days) & \% Fe leached & \% Zn leached \\
\hline Bac & 20 & 15.8 & 45.86 \\
\hline Rhl's & 1 & 6.26 & 3.21 \\
\hline \multicolumn{2}{r|}{ \% Total Leachate } & $\mathbf{2 2 . 0 6} \pm \mathbf{0 . 4 2}$ & $\mathbf{4 9 . 0 7} \pm \mathbf{0 . 1 8}$ \\
\cline { 3 - 4 } & &
\end{tabular}

Rhl's = rhamnolipids solution

Bac $=$ Bacteria culture 


\section{ACCEPTED MANUSCRIPT}

Table 6. Percentage of $\mathrm{Fe}$ and $\mathrm{Zn}$ dissolved after an alternate cyclic test (RhL's/Bioleaching/RhL's) starting with a washing test with1 mg/mL RhL's (v/v) for $24 \mathrm{~h}$, then a bioleaching test with a mixed culture of Acidithiobacillus every 7 days.

\begin{tabular}{|c|c|c|c|}
\hline Treatment & Time (days) & $\%$ Fe leached & $\% \mathrm{Zn}$ leached \\
\hline Rhl's & 1 & 17.39 & 53.86 \\
\hline $\mathrm{Bac}^{*}$ & 7 & 1.19 & 2.93 \\
\hline Rhl's & 1 & 5.07 & 2.00 \\
\hline Bac* & 7 & 1.59 & 4.07 \\
\hline Rhl's & 1 & 5.86 & 2.29 \\
\hline $\mathrm{Bac}^{*}$ & 7 & 1.42 & 3.00 \\
\hline Rhl's & 1 & 3.54 & 1.79 \\
\hline & $\%$ Total Leachate & $36.06 \pm 0.268$ & $69.94 \pm 0.118$ \\
\hline
\end{tabular}

* Treatment with bacteria performed in each mineral residue after washing.

Rhl's = rhamnolipids solution

$\mathrm{Bac}=$ Bacteria culture 


\section{ACCEPTED MANUSCRIPT}

Figure 1. Stages of the sequential extraction procedure (Brady et al., 1999).

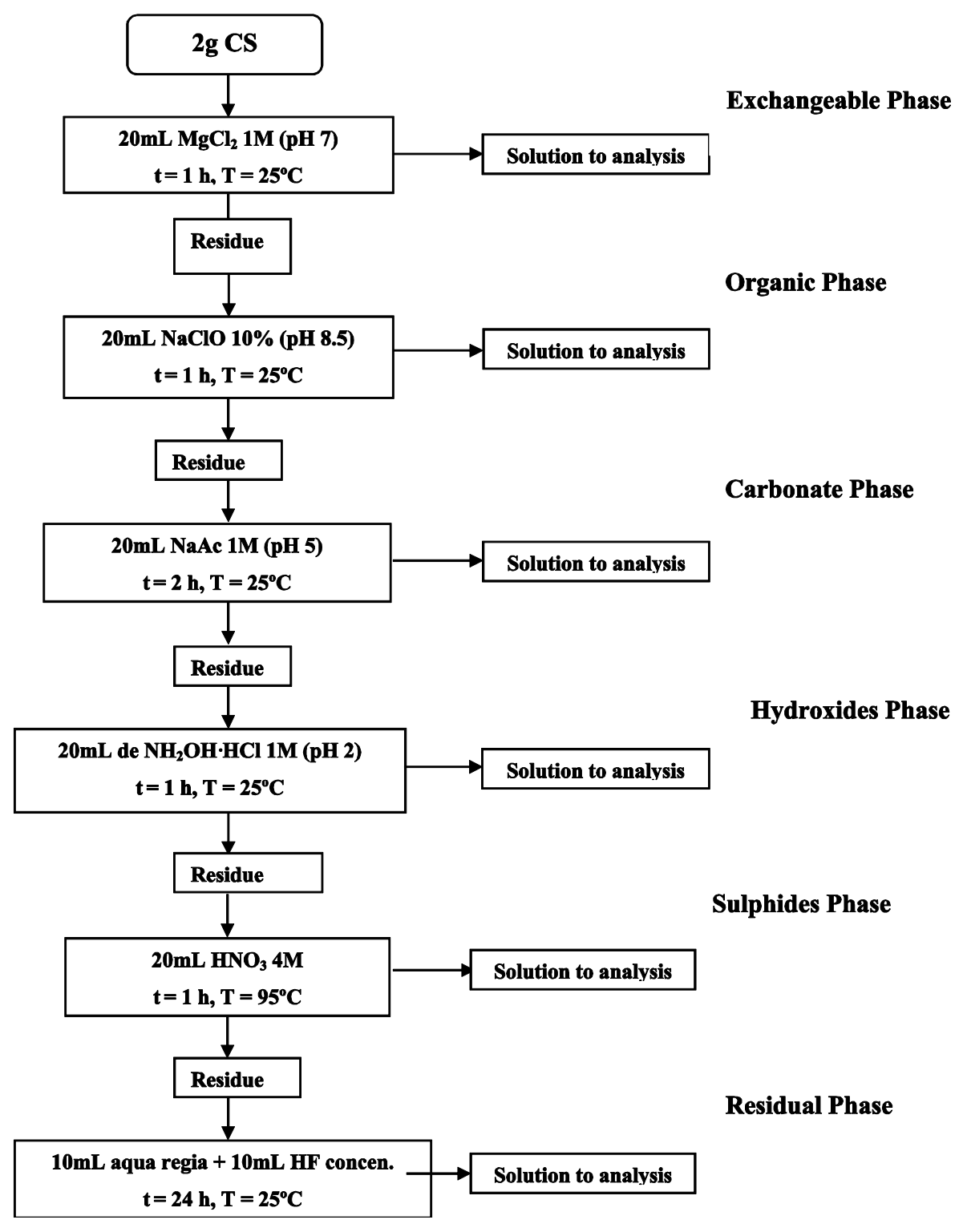




\section{ACCEPTED MANUSCRIPT}

Figure 2. Stages of the cyclic treatment (each stage was repeated for a period of 25 days).

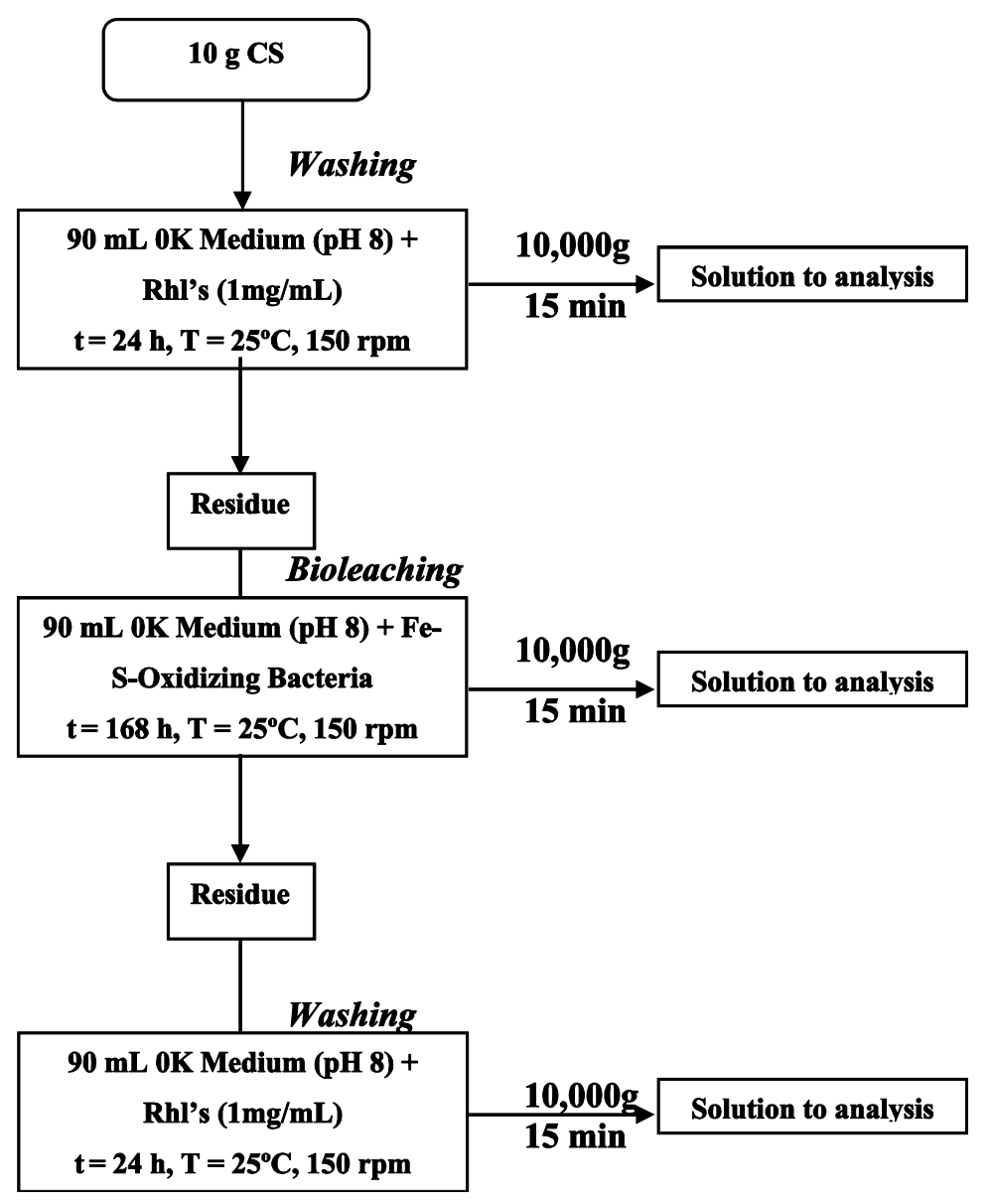




\section{ACCEPTED MANUSCRIPT}

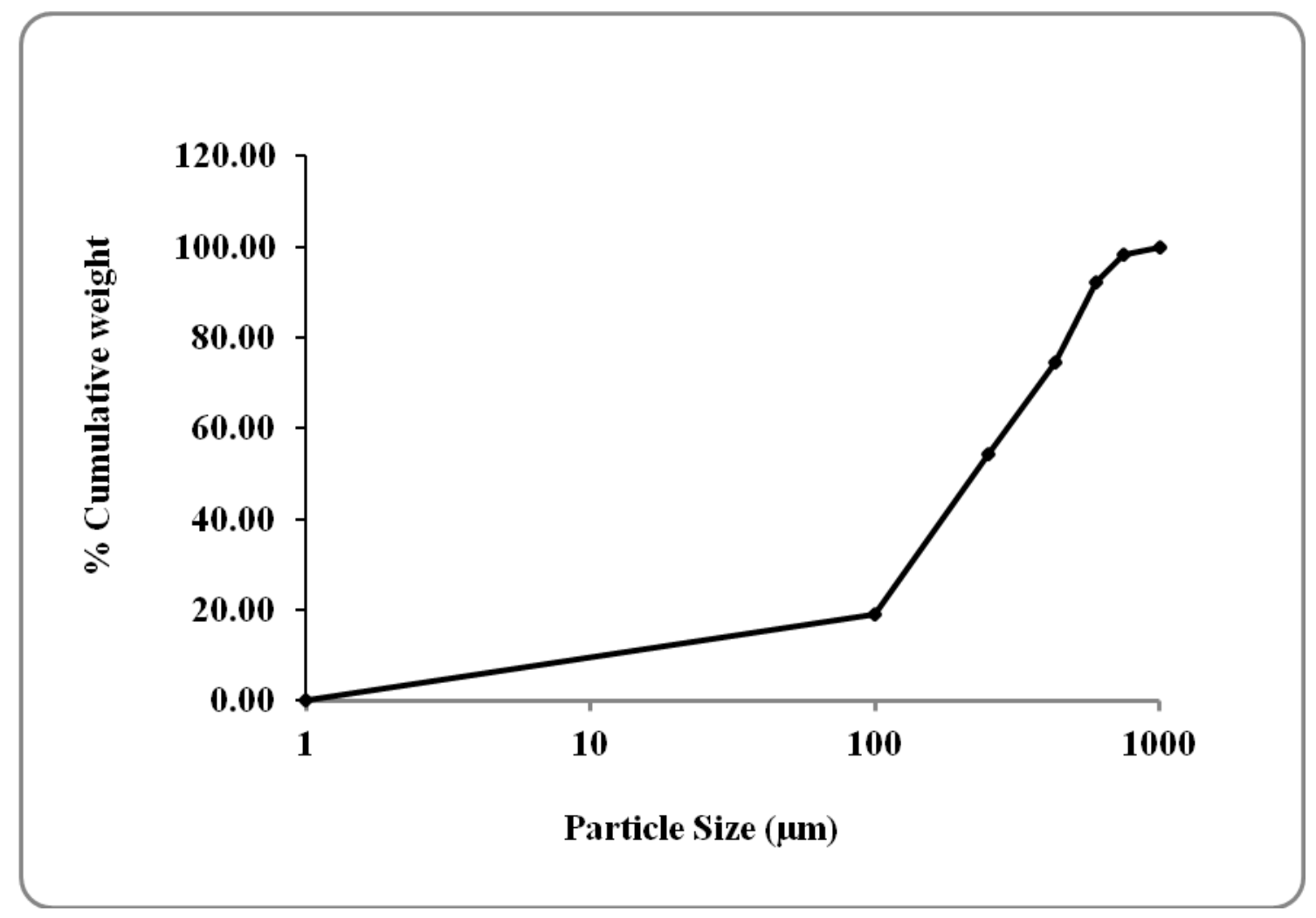

Figure 3. Granulometric size distribution analysis of the contaminated soil. 


\section{ACCEPTED MANUSCRIPT}

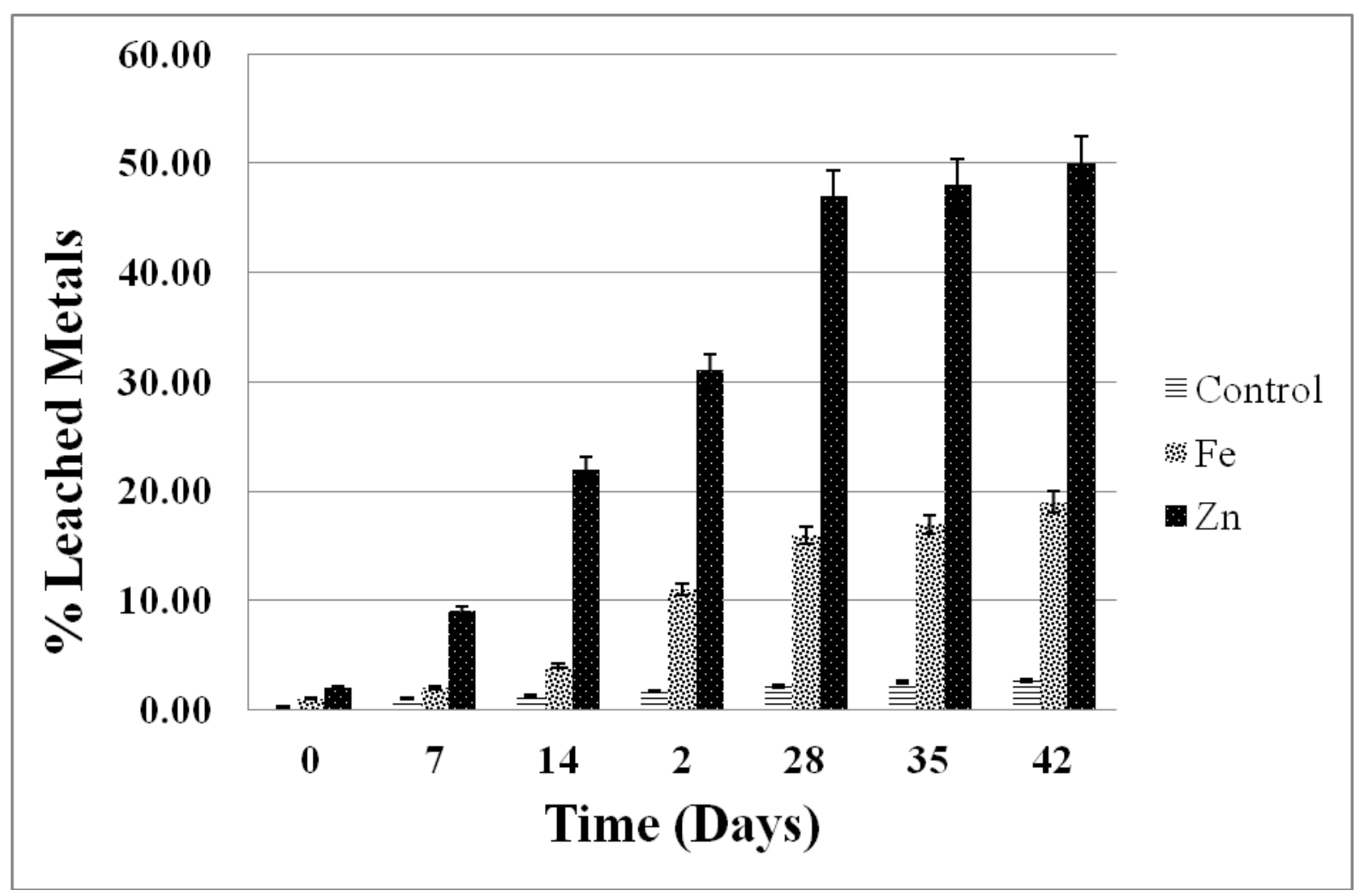

Figure 4. Percentage of metal dissolved ( $\mathrm{Fe}$ and $\mathrm{Zn}$ ) in the microcosm test with a mixed culture of Acidithiobacillus after 42 days of bioleaching. Notice that deionized water was used as control for all the experiments. 


\section{ACCEPTED MANUSCRIPT}

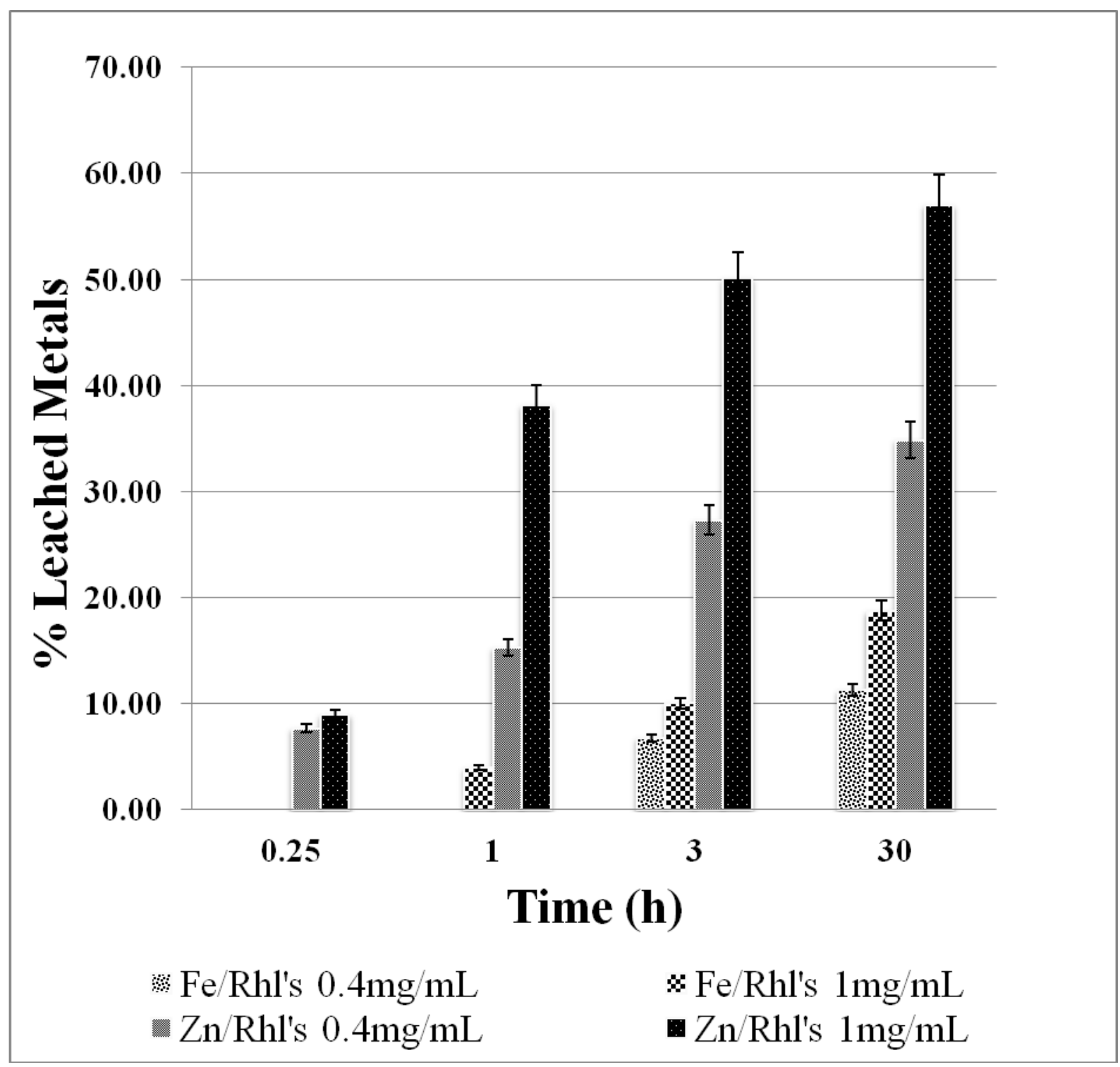

Figure 5. Percentage of $\mathrm{Fe}$ and $\mathrm{Zn}$ dissolved in washing tests with two different concentrations of rhamnolipids $(0.4$ and $1 \mathrm{mg} / \mathrm{L})$ after $30 \mathrm{~h}$. 